\title{
Injurious Effects of Hate Speech Acts in The Bluest Eye
}

\author{
Tamsila Naeem $^{1} \&$ Nadia Anwar ${ }^{1}$ \\ ${ }^{1}$ University of Management and Technology, Lahore, Pakistan \\ Correspondence: Tamsila Naeem, University of Management and Technology, Block C-II, Block C 2, Phase 1, \\ Johar Town, Lahore, Punjab 54770, Pakistan. E-mail: tamsila.naeem@umt.edu.pk
}

Received: July 21, 2019 Accepted: August 18, 2019 Online Published: October 13, 2019

doi:10.5539/ijel.v9n6p106 URL: https://doi.org/10.5539/ijel.v9n6p106

\begin{abstract}
This qualitative study aims to investigate the effects of hate speech acts of powerful agencies, which are used to establish and maintain power relations by influencing the psyche of minorities or weaker groups to assign them a subordinate position. In the light of Judith Butler's notions presented in her famous book Excitable Speech (1997) it is found that such acts are used as a linguistic weapon in the process of social domination. Hate Speech acts have an injurious effect on the psyche of the weak which prompts them to obey the commands of the speakers, the powerful. For this purpose, relevant excerpts were taken through purposive sampling technique from Toni Morrison's novel, The Bluest Eye (1970), which depicts the tragic conditions of a black family living in a race conscious society of America. They are considered inferior to the white at social, moral, economic and political levels. The analysis of the selected texts is done at both micro and macro levels. At the micro level, the lexical semantic features of the utterances are studied and at the macro level, the socio-political environment in which the black characters are victimized and then psychologically subjectified is discussed. It is seen that the feeling of being ugly has multiple and terrible influences on the mind and body of the subjects. The selected episodes from the novel are the manifestations of their wounded psyche in the white-dominated America. They unconsciously think themselves as agents of darkness, sin, crime, wickedness, immorality and evil. The findings of the study also reveal a taxonomy of newly emerging hate speech acts which may prove useful to analyze the communicative patterns of race-driven societies.
\end{abstract}

Keywords: hate speech acts, power relations, injurious effects, wounded psyche

\section{Introduction}

Psychologists such as Sigmund Freud (1856-1939), sociologists such as Michel Foucault (1926-1984) and psycho-linguists such as Jacques Lacan (1901-1981) believe that the human psyche is always influenced by the surrounding environment. Judith Butler as a philosopher, rooted in linguistic formations, in her famous book, Excitable Speech (1997) extends Austin's theory by postulating that language has "a power to injure", when it "acts against us" (1997, p. 1). In the very beginning of this book, Butler gives arguments to support her views on the role of insulting language in subject formation. She moves on to identify those expressions framed in specific linguistic mechanism, which can injure the victim's psyche. Hence the mode of linguistic injury is equally important as the insulting words are. In this process, all the subjects are positioned as objects of insult (1997, pp. 1-2). Mary Kate McGowan in New Work on Speech Acts describes the speech acts, which enact facts. These speech acts are termed by Austin as "exercitive" (Fogal, Harris, \& Moss, 2018, p. 188). Butler's interest also lies in the interpellative aspect of speech, which is not observed as true or false, rather its major aim is to establish, indicate and maintain subjects in their hierarchical positions. In this regard Butler tries to highlight certain features of hate speech, which are used to reduce the addressee into a subservient position.

It is assumed that language not only acts, but it also injures the addressees to affect them mentally and affix them as subjects. It is mandatory to have a hierarchical position between the speaker and the listener, who eventually not only gets injured, but his/her social rank is also re-established through a perlocutionary effect. In this context, a linguistic injury works to establish power relations in a society. Butler quotes Mari Matsuda (1956), an American lawyer to support her arguments, "speech does not merely reflect a relation of social domination; speech enacts domination", when it becomes a tool or an 'agency' to reconstruct social foundations (Butler, 1997, p. 4). By exposing the metropolitan values, Butler underscores the persistence of hate speech in the form of illocutionary acts. In this regard the influence of Austin on her thoughts cannot be overlooked. In Bodies That Matter, Butler (1996, p. 16) in response to a question raised by Bergman; "What counts as normal?" states that it is 
the consideration of norms, values and ways of life that makes one's life normal. The response shows Butler's curiosity about an unseen verbal constitution that serves as an archetypal image, imposed upon individuals by society in order for them to look normal. It is on these standard grounds that identities of different individuals such as male, female, black, white, and brown are recognized. In the preface of his book, The Scandal of the Speaking Body: Don Juan with J. Austin, or Seduction in Two Languages, Felman (2003), acknowledges that after Judith Butler's interest in performatory aspects of language, the theory of speech acts has been considered very important in understanding different social, political and psychological issues, such as gender discrimination, sexual abuse, verbal abuse, cultural diversity and post-colonial identity crisis.

Judith Butler's book Subjects of Desire, Hegelian Reflections in Twentieth-Century France (2012) (Note 1) examines the influence of Hegel's thoughts on some eminent philosophers such as Sartre, Foucault and Lacan. Her ideas about performative politics were influenced by a theory of subject formation propounded by George Wilhelm Friedrich Hegel (1770-1831). Hegel's notions are reflected in all of Butler's works; whether she debates about subjectification or about gender. Hegel considers two types of forces equally important in the construction of one's psyche: inner forces termed as internal otherness and outer forces termed as external otherness. He is of the view that it is after the realization of a reciprocal relationship between the position of the subjects and the position of the masters that subjects are inclined to be under their control. In his opinion, the concept of internal other exists in an ambiguous manner because it is different from the inherent self. He comments that the subjects are constructed under the influence of their own individual traits as well as the universal traits. Butler objects Hegel's ideas on the grounds that it is not possible to think about the things which are unshaped. Structures in this unlimited universe can never be approached. In Contingency, Hegemony, Universality (2000), Butler contends: "even in an attempt to maintain our individuality, there is need to constitute a proper inside first, which can be differentiated from other identities on the basis of similarities and differences" (2000, pp. 144-145). She considers the performative politics as a progression or a movement in the formulation of subjective and sexual identities. Her notions about subject formulation enjoy a central position in her debates on performatory aspects of language. She believes that subjects are formed when in specific conditions the external constitutive inside or "the temporal side of identity" as well as "constitutive outside" works on them (Butler et al., 2000, p. 180). In this regard, it is the psychological subjugation of the subjects that is under the influence of Hegelian theory of subject formation.

According to Sarah Claeys (2007, p. 5), Butler's focus is on the ability of speech, which makes people uncomfortable and hence makes them ponder on it to find solutions. She is concerned with that type of speech, which is used to create disturbance in the life of people at the socio-political level. When people, especially those who are in power use injurious words against weaker bodies, the mind of the latter is bruised first, followed by a debilitating effect on their body. In this regard a linguistic injury turns out to be as much offensive as the physical injury, wounding people both mentally as well as physically. Butler goes to the extreme, when she describes the killing effects of speech, which assist in the perpetuation of violence, "If language can sustain the body, it can also threaten its existence" (1997, p. 5). On the one hand language enables the speakers to exert their violent force on the hearers (language of violence) and on the other hand the hearers are silenced through oppression. Butler sees the manner of speech equally powerful as are the injurious words.

Toni Morrison also believes in the performatory aspects of language. She establishes an interactive relationship between her and her readers through literary speech acts in her novels. She wrote her novels on multiple subjects like racism, ethnicity, slavery, colonialism, post colonialism, gender discrimination, feminism, motherhood, marginalization, polyvocality and psychological suppression, among others, which were analyzed by many researchers such as McDowell (1988), who explored elements of self in her novels, Dixon (1990), who highlighted Morrison's contribution in presenting the themes of alienation and discovery of self, Wang Lei (2011), who studied the elements of psychological trauma on the black people in her novels, Bouson (2000), who made psychoanalytical study to discover elements of shame and trauma theories in her novels, and Burrows (2004), to name a few, who scrutinized the mother-daughter relationship in the contexts of racism, supremacy of the white and trauma in her novels in the fields of discourse analysis and literary criticism. Lister remarked that Morrison addressed "issues that have been distorted or denied by the official accounts of history" (2009, p. 21). She gave voice to the enslaved souls to bring to surface their psychological agonies and to make the surrounding people aware of the pain of being ruled. She claimed, "I felt I represented a whole world of women who either were silenced or who had never received the imprimatur of the literary world" (Lister, 2009, p. 8). In almost all of her novels, there is a projection of wounded black psyche under white threats.

The white characters in Morrison's novels do not consider the black characters at the level of human beings. They use insulting tone, sarcasm, and rude mannerism in order to humiliate the black characters. Elijah remarked in his 
article, The Emerging Philadelphia African American Class Structure, "along with slavery... came a white supremacist ideology that defined black people as less than human, as genetically inferior to the country's majority" (Anderson, 2000, p. 12). According to Cynthia Davis, "All of her characters live in a world, which is defined by the ruling class of the White people, which denies their basic rights as humans" (Davis, 1998, p. 10). There are events of rape, atrocities, verbal and physical abuse, identity crisis, victimization, hopelessness and exploitation in almost all the novels produced by Morrison (Note 2). According to her to call someone "nigger" for example, means to inflict mental torture on her/his psyche whereby the hate speech is acted successfully. In The Bluest Eye (Morrison, 1971), Cholly is addressed by the White in different situations as "dirty nigger" (p. 189), when he was being discussed for his heinous act of rape of his own daughter, and as "an old dog, a snake, a ratty nigger" (p. 18), and when he was seen by two men with a girl in the bushes, the hate speech blurted out in the form of, "And, nigger, make it good" (p. 42). Morrison's Beloved is also full of such addresses; "Breakfast? Want some breakfast, nigger? ... Hungry, nigger?" (p. 63). In the same manner, in Sula the Black community's miserable plight was described as "Niggers was dying like flies" (p. 69), as if they were as ordinary and worthless in the White dominated society as the flies were. Coupland critiques the "pejorative" and "racist" overtones of the term 'niggers' which "solidifies and naturalizes our represented worlds" (Jaspers, Verschueren, \& Östman, 2010, p. 242).

\subsection{Research Questions}

The following questions are asked in the present study:

- How do hate speech acts in the form of authoritative utterances of the powerful white characters have injurious effects on the psyche of black characters in Toni Morrison's The Bluest Eye?

- How do these injurious effects bring the victims to the level of psychological subjugation?

- How do the hate speech acts give birth to other relational speech acts?

\subsection{Research Objectives}

In order to find responses to the research questions, the following objectives have been framed:

- To scrutinize the injurious effects of hate speech acts on the victims' psyche in the light of Judith Butler's hate speech acts.

- To evaluate the process of psychological subjugation of the black characters under hate slur.

- To discover newly emerging speech acts relational to hate speech acts.

\section{Method}

\subsection{Theoretical Underpinning}

In this qualitative study, Judith Butler's theoretical framework of hate speech acts presented in her book Excitable Speech is applied on the selected texts. Hate speech is used by a group of people or an individual, who enjoy/s an authoritative position to use the most suitable words to play with the psyche of the subjects. In this regard, hate speech is highly rhetorical as well as political. The role of hate speech is conceived at two levels in The Bluest Eye. In the first type the powerful white deliberately use humiliating discourse as a weapon of insult in order to represent negative other against the weaker communities, which may fix the latter at subjected position. At the second level the effects on the psyche of the weaker communities are studied.

\subsection{Data Collection}

The data were collected from Toni Morrison's novel, The Bluest Eye, which reveals duplicitous and contentious signs of established norms of beauty in American society. The novel is a tragic description of a black family living in a race conscious society of America. All the members of Breedlove family are treated unfairly due to racial discrimination. They are denied their basic human rights, which the other people, especially the white had, including rights to avail good job opportunities, proper houses to live, and respectable social status. The white is shown to stimulate hatred for the black in their attempts to promote their own cultural norms and standards through means of print media, social media and verbal abuse. The research criterion in selecting this novel and afterwards in selecting relevant texts/excerpts is based on their relevance with the aim and objectives of the study. In this regard, the criteria of the selected excerpts are pre-defined, hence purposive. According to Adler and Clark (2014, p. 121), "In purposive sampling, the researcher selects sampling units based on his or her judgement of what units will facilitate an investigation". After a close study of the selected novel, different events, situations and expressions are selected to study the injurious effects of hate speech on the major characters of the novel, such as Cholly, Pauline and Pecola. The hate speeches of the white reflecting the denigration of the black are brought 
forth by distant markers, linguistic contrasts of positive self and negative other, authoritative use of denotative and verbal dichotomy to display "in-group" and "out-group" strategies. Occasionally such stereotypical attitudes of the powerful people affect the victims' mind in such a manner that they tend to mentally internalize it. For instance, in The Bluest Eye, all the family members of the Breedlove family shared one single norm that they were terribly ugly, and consequently, their entire shortcomings upshot from this very reality.

The research of such a study tends to be subjective mainly due to the fact that it is done in accordance with the researcher's own experiences and associations. However; the manner of hate speech is defined by the context of the utterances which allows sufficient objectivity to the researchers to indicate and evaluate the speech acts and their effects.

\subsection{Analysis Design}

The selected texts are categorized into two units. First, a derogatory hate speech act is selected, which is uttered by a powerful white character in the novel, the Master of the house. Second, the texts displaying the traces of psychological injuries as perlocutionary effects, on Cholly Breedlove, Pauline Breedlove and Pecola Breedlove are selected. The figure below shows the methodological framework of the analysis:

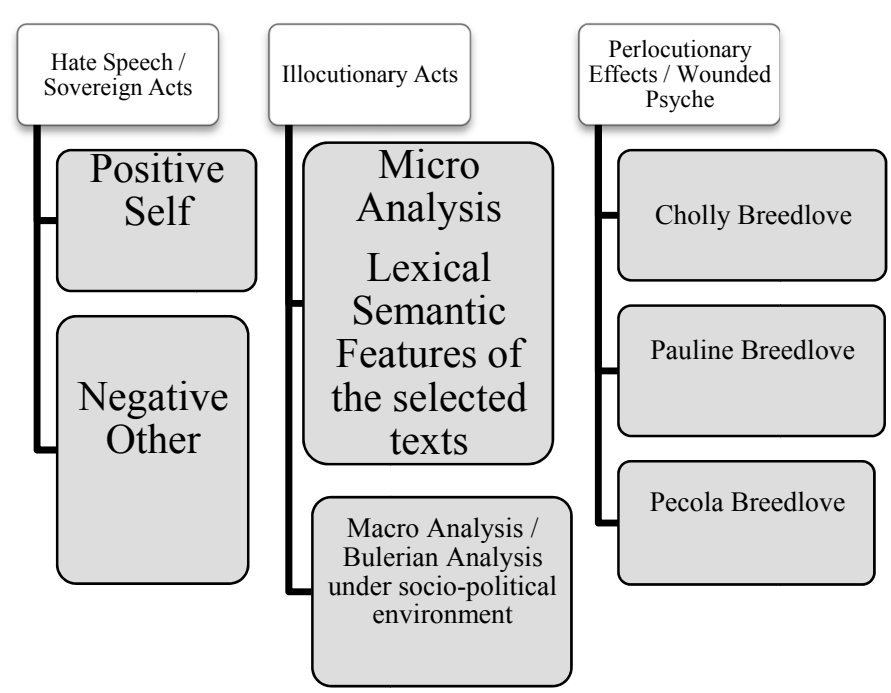

Figure 1. Analysis design under Hate Speech Acts

\subsection{Analysis Sections}

The analysis of the selected texts is done at two levels: micro and macro. At the micro level, the selected texts are broken down into smaller components at the levels of words, phrases and simple sentences to study their functions, which contribute in making different types of speech acts good performatives. Every word is used by the novelist very tactfully to reflect the hostile socio-political environment in which the black characters are instituted as subjects. In order to interpret the psychological effects of the speech on the addressees, it is necessary to study the lexical semantic (Note 3 ) features of different utterances. These features include different terms such as self-praise/denigration of other, distant markers, use of adjectives, types of speech acts, use of determiners and verbal dichotomy, etc.

\section{Data Analysis \& Discussion}

\subsection{Ugliness: As a Hate Speech Act}

Excerpt 1: "The master had said, 'You are ugly people.' They had looked about themselves; saw nothing to contradict the statement; saw, in fact, support for it leaning at them from every billboard, every movie, every glance. 'Yes' they had said. 'You are right'” (p. 39).

\subsubsection{Micro Analysis}

This communicative event takes place between the owner of the house and Breedlove family members. The owner is a white American, who enjoys a respectable position in the society. He declares the black ugly, a charge the latter accepts passively. The text carries a bold derogative illocutionary act and an acknowledgement as its 
perlocutinary effect. In this utterance, it is realized that "The master" is a dominant figure, who can be taken as powerful agent in the production of illocutionary hate speech act, used to push Breedloves at the lower rank. His authoritative position enables him to assume himself to be "the master" of the house as well as of the fate of Breedloves. The knowledge of the self and the other makes him use rhetoric which can make them acknowledge their inferior status in the society. The use of pronoun "you" is used as a marker of insult at generic level. "You", the second person deixis, refers to Breedlove family members at the micro level, but at the macro level, it includes all the black people living in America. When people, especially, those who are in power find others to be different from them, they develop a discourse of "you and I" to express their hate for the others. The word "you" itself creates the idea of otherness (Note 4) in the construction of identities of powerful agencies and minorities. In such stigmatized interactions, the powerful people establish and maintain their identities. In the present context, the master is aware of his own superior status to the marginalized Breedloves. He adjusts his behavior accordingly to perpetuate and sustain greater social and political power. Hence, with a clear self-image about his white skin, brown hair and blue eyes, the master places the Breedloves on the plinth of ugliness, since they possess black skin, black hair and black eyes. Considering himself as fair and nice, he declares them as "Ugly people". The word "people" is a generic term, which includes all the black people, living in America of that time. The social discrimination and its resultant psychological disorders are shown to be reflected in their interactions and actions with each other in different situations.

Both the addressor and the addressees are aware of the binary oppositions constructed under an unseen verbal constitution. Since, being ugly is associated with darkness and darkness is perceived as evil, the members of Breedlove family consider themselves as embodiments of evil. In this regard, the word "ugly" being a hyponym contains multiple senses, all negatively driven. As a consequence, this feeling of being ugly has multiple and terrible influences on the psyche of the black. The response, "Yes", is a comprehensive denial to their existence since saying "yes" is a token of submission. They develop a sense of loss as a consequence of the very declarative statement, but they cannot deny the fact that their ugliness is unique. It is natural, since the notions of omnipotence and superiority are entrenched in the construction of such identities. "You are right", "they said" is that submission which gives all the members of Breedlove family a collective identity. In this regard it is shown that all of them are concurrently affected psychologically by the master's judgement about them. Cholly, Pauline, Sam and Pecola are correspondingly conscious of their ugly dispositions. They cannot offend the white master, hence they readily admit to his statement.

The use of the determiner "the" with master by the novelist demonstrates that there are many other masters like the one in the context. Morrison attributes authoritative power to the master of the house. He has sufficient knowledge of Breedloves' socio-economic status, and hence he treats them accordingly. The indefinite pronoun 'every' is used in the broader context, and it includes all the referred objects. It confirms the overall establishment of white aesthetics and supremacy of the white in all walks of life. The black are ordinary people, who cannot grow and flourish on the land, which turns out to be barren for them. The Breedlove are no more in a position to challenge the statement because they are absent from the space where "every billboard", "every glance", "every movie" advertised white aesthetics of beauty. Hence, after self-recrimination in the hostile environment, which excludes them from everywhere, they submit.

\subsubsection{Macro Analysis}

A variety of authoritative derogatives is used and repeated both implicitly and explicitly through different sources to advertise and promote white aesthetics in the society. All such attempts divide the people into binaries, which are used to centralize one group and de-centralize the other group. The Breedlove believe that they are ranked at the margins. They are conscious of their marginalized status due to social discrimination on racial grounds. Their ugliness is basically an outcome of the social environment in which they are misunderstood by other people, who take them as personifications of different types of crimes, sins and evil. The civilized people are 'the pure opportunists' who enslave the others as their inherent right.

The whole novel is a description of anxieties faced by Cholly Breedlove in a series. Cholly grows as a forsaken child by his parents. Being devoid of his identity and social recognition, he does not have any concept of parental love and tranquility of a family life. Pauline's history and self-experiences are also very bitter, because she has never felt at home with anyone. Their daughter, Pecola has also been a victim of abuse at all levels, social, domestic and psychological.

\subsection{Injurious Effects of Hate Speech on Cholly Breedlove}

Excerpt 2: "It must be the devil who looks like that-holding the world in his hands, ready to dash it on the ground and spill the red guts so niggers could eat the sweet, warm insides" (p. 56). 


\subsubsection{Micro Analysis}

This communicative event is the reflection of perlocutionary effects of hateful utterances on the psyche of Cholly Breedlove. It takes place when he sees his own reflection in a mirror. In the novel, he is presented as a threat not only for the society but for the humanity in general. As a devil incarnate, he has no sense of doing anything in the name of God which propels his own community to call him "an old dog, a snake, a ratty nigger" (p. 18). By attributing great power to the devil as a supernatural being, Cholly clearly draws a line between the white and the black. It is surely in line with Satan's speech in John Milton's Paradise Lost (Note 5): "Doing or Suffering: but of this be sure, to do ought good never will be our task" (Milton, 1905, p. 8). Cholly being a pessimist, is convinced that the whole world is controlled by devil. Since he believes that God is kind only to the white only, the devil will destroy their world and will shower warm and sweet food only to the black. Being a mighty figure, the devil is capable of running the world's business according to his planned designs. He seems to be in opposition to the divine scheme of nature, which bestows its blessings only on the white. In this regard, this excerpt is also categorized under self-divergence, since Cholly disassociates himself from the world of the white.

Use of the definite article "the" with "world" and with "sweet" makes them proper nouns. It is the devil, who holds "the world" in its hands. It shows that Cholly perceives the devil as a monster, as a destructive agent, who can hold the world only to dash it on the ground. Black people, according to him must be on the other side: the devil's side. Cholly's favorite food is described by using different adjectives. The way he blurs the images of watermelons with "red guts" is highly symbolic because these red guts with warm insides can also be taken as small pigs. The description reflects Cholly's savageness, because he is thirsty for red and warm blood, for uncooked warm inside of pigs. It also reflects brutal, ruthless, vicious and inhuman features of his personality. He draws a logical conclusion, when he uttered "it must be", which reflects clearly the influence of hateful discourse on his psyche, he had received from the white community.

\subsubsection{Macro Analysis}

This excerpt is the representation of self-recrimination of Cholly as an agent of devil, which leads him to subversion or moral fall. To avenge on the racial discrimination of the black, he tries to be on the devil's part consciously as well as unconsciously. Although he knows that devil's figure stands for evil, yet he believes that only it can provide the black people food and other necessities of life. He gets psychological power in his association with the devil. He expects two different tasks from the devil. First, it should destroy the world, which is not ready to accommodate the black people and second, it can bestow the niggers plenty of food "red guts" to satisfy their hunger.

According to Fanon (Note 6), "when the black man comes into contact with the white world, he goes through an experience of sensitization. His ego collapses. His self-esteem evaporates. He ceases to be a self-motivated person" (Fanon, 2008). This aspect becomes more meaningful and consequential, when later in life Cholly rapes his own daughter and burns his house. In other words, the mortifying behavior of the white indirectly tempts him, although covertly, to do malicious deeds. In Cholly's inclination towards the devil, Morrison seems to make her readers believe that the black under the effects of hate speech acts have become inherently wicked.

\subsection{Injurious Effects of Hate Speech on Pauline Breedlove}

Excerpt 3: "Often she could be heard discoursing with Jesus about Cholly, pleading with Him to help her "strike the bastard down from his pea-knuckle of pride" And once when a drunken gesture catapulted Cholly into the red-hot stove, she screamed, "Get him, Jesus! Get him!" If Cholly had stopped drinking, she would never have forgiven Jesus. She needed Cholly's sins desperately. The lower he sank, the wilder and more irresponsible he became, the more splendid she and her task became. In the name of Jesus" (p. 42).

\subsubsection{Micro Analysis}

These odious utterances or aggressive speech acts are the representations of Pauline's extreme hatred towards her husband. Their counter accusations also fall under categories of self-recriminative and self-derogative speech acts, since both husband and wife blame each other for their failure and misfortunes and not others. The word "often" signifies the frequency of their quarrels. Such disputes on daily basis are the proof of their mentally disturbed married life. In all Pauline's attempts to motivate Cholly to feel his responsibilities towards his family, she gets badly hurt. Her abusive utterances and curses for him are acts of retaliation in this context. She has never been able to enjoy the feelings of security, care and love, which are associated with his role as a husband. "Strike the bastard down" is an extremely rude derogative. A chain of negative connotations associated with "bastard" indicates that this subverted image of animus archetype is wicked, mean and illegitimate, etc., who has lost love and respect in the eyes of its wife. Her contemptuous behavior, in which she addresses Jesus, shows that she is quite unaware of 
the ethics and manners desirable and acceptable in praying to Jesus. Her repeated shouting "Get him" appear to be derogatory commands rather than polite requests, thus even subverting the religiously codified behaviour expected of her. Another significant point in this connection is that she regards herself as an innocent victimized woman; hence she believes that Jesus will help her. Her act of being engaged in discourse with Jesus is an endorsement of her confidence that he listens to her grievances.

Pauline's unresolved anger and extreme hatred knows no bounds. She has strong grudge against her husband. When she finds herself helpless in adverse circumstances, she prefers to destroy her world in the form of fall of her husband. She curses him to be the target of God's wrath and prays for his death. She appeals Jesus to punish him hard and take his soul, because she believes that those who trouble others' life should be troubled by Jesus. The use of comparative degrees of adjectives used for the husband and wife highlights the understanding gap between them. The dichotomy between "lower" and "splendid" indicates that she considers herself to be an opposite of her husband. She will be blessed if he is punished, because more he "sinks" more "sublime" she will be. The metaphorical image of the drunkard Cholly as "the red-hot stove" establishes a link between him and the infernal world.

\subsubsection{Macro Analysis}

A famous biologist Jean Piaget (1972) developed various theories, which illustrated different phases of acquisition of moral values among children. He believes that children learn everything from the environment they are surrounded by. The Breedlove never enjoy their sense of belongingness but on the contrary they are dreadfully affected by the lack of attachment. Marriage and motherhood fail to influence Pauline. She likes to live in the world of imagination or in the world of movies, where everything is according to her desires. She yearns for love in order to survive in the society but her limp foot and decayed front teeth add to the ugliness as well as deformity to her character, which set the foundation of her personality reception. On the other hand, Cholly is morally wicked because he fails to perceive any image of mother, father, brother and sister in his life. He has been a rejected and abandoned person throughout his life. He has been thrown "outdoor" by the community as well as by the society at large. He is enslaved by a belief that he must be a devil. Both Pauline and Cholly want to get rid of their identity as black people, since it cannot bring them status and respect in the society. This strange combination of life and death provides them an idea of struggle, a struggle to fight for their recognition. All these factors are responsible for the wounded psyche, they bear: "Dichotomies of racial superiority and inferiority, humanness and sub-humanness, had yet to claim en masse the popular and, later, national psyche" (Lynn \& Jennings, 2009).

\subsection{Injurious Effects of Hate Speech on Pecola Breedlove}

Extract 4: "Please, God" she whispered into the palm of her hand, "Please make me disappear" (p. 43).

\subsubsection{Micro Analysis}

This text indicates Pecola's mentally as well as emotionally disturbed condition, which is an outcome of hate slur; she is destined to receive from everyone. This speech act is self-deviative in the form of a polite request made to God to take her away from this miserable and tormenting life, finds her survival in disappearing but her eyes always refuse to do so, they are left to see the world of hatred around her. Morrison writes about the real-life girl, who replicates Pecola. Morrison in the "Foreword" of the novel proclaims that she can never be able to forget this little girl's desire, which appears to her quite illogical. Within the parameters of the dark world of ugliness, idealistic and propagative outcomes of love and desire are disillusioned; hence she was unable to know the true meanings of love and desire:

Implicit in her desire was racial self-loathing. ... who told her? Who made her think that it was better to be a freak than what she was? Who had looked at her and found her so wanting, so small a weight on the beauty scale? (p.11).

The repetition of "please" intensifies the degree of request. Her act of making requests "into the palm of her hand" denotes the universally established gesture of praying to God, which she might have adopted from the society. Her manners of praying are in contrast with her mother's manners of praying, since the latter screams loudly, when she pleads to Jesus (p. 42). There is a strong hidden cry in her "whisper" which shows that she is terribly afraid of raising her voice in her house in order to protest against her misfortunes. She has lived a passive life because she has been a victim of social and domestic suppression, subsequently she will be easily subjugated by anybody under any circumstances. She is further isolated in the world, when she becomes the victim of her father's sexual assault. After her rape she reports to her mother, who is least concerned with this tragic intercourse and instead of consoling her victimized daughter, scolds her. Her mother shows no sympathy to her; hence she does not raise 
her voice to protest the same act for the second time (p. 215).

Use of pronominal "me" shows that she is conscious of her "self" and "ego". She does not like to become a part of the world she inhabits. This is also realized by the narrator, when she feels desperate at the death of Pecola's baby: "This soil is bad for certain kinds of flowers" (p. 206). The determiner and deictic "this" refer to the soil of race conscious American society before the Civil Rights Movement in America (1950-1960). The metaphoric use of "soil" for America and "certain kinds of flowers", especially "marigolds" for black people indicate that the black will not be given a chance to grow there.

\subsubsection{Macro Analysis}

Pecola Breedlove, the protagonist of the novel is subject to hateful speeches made not only by the powerful white, but by her parents as well. She suffers because her apparent archetype is ugliness, which is not liked by anybody. Her desire for social acceptance fails desperately in spite of all her attempts, and she gets insane consequently. Among all the family members in the Breedlove family, she is the most insecure person as Morrison remarked: "I focused, therefore, on how something so grotesque as the demonization of an entire race could take root inside the most delicate member of society: a child; the most vulnerable member; a female" (Hamlin \& Jones, 2010, p. 309).

Through Pecola's character, Morrison tries to engage her readers in a close relationship with the wounded psyche of black community. Moran (2015) quotes Morrison, when in 1993, she justified the story of Pecola Breedlove in these words:

The extremity of Pecola's case stemmed largely from a crippled and crippling family - unlike the average black family and unlike the narrator's. But singular as Pecola's life was, I believed some aspects of her woundability (italics mine) were lodged in all young girls. In exploring the social and domestic aggression that could cause a child to literally fall apart, I mounted a series of rejections, some routine, some exceptional, some monstrous, all white trying hard to avoid complicity in the demonization process Pecola was subjected to (p. 55).

Morrison believes that wounded psyche is not limited to Pecola only rather it is a general dilemma of all the black girls like her.

\subsection{Synopsis of Lexical Semantic Features}

The following table presents different lexical semantic features categorized into different sections:

Table 1. Lexical semantic features of hate speech acts

\begin{tabular}{|c|c|c|c|c|c|}
\hline & $\begin{array}{l}\text { Use of Determiners / } \\
\text { Used for } \\
\text { surveillance }\end{array}$ & $\begin{array}{l}\text { Deictic Markers / } \\
\text { Used as markers of } \\
\text { otherness }\end{array}$ & $\begin{array}{l}\text { Use of } \\
\text { Adjectives / }\end{array}$ & $\begin{array}{l}\text { Verbal } \\
\text { Dichotomy }\end{array}$ & $\begin{array}{l}\text { Emerging Speech Acts } \\
\text { under Hate Speech Acts }\end{array}$ \\
\hline Excerpt 1 & The, you, they & You, every & Ugly & You-every & Derogatives, Submissives \\
\hline Excerpt 2 & The, who, that, it & & $\begin{array}{l}\text { Red, sweet } \\
\text { Warm }\end{array}$ & $\begin{array}{l}\text { Holding, Dash it, } \\
\text { spill the red guts }\end{array}$ & $\begin{array}{l}\text { Self-recriminatives } \\
\text { Self-deviatives }\end{array}$ \\
\hline Excerpt 3 & Often, the, his, her & She, he, Him, her & $\begin{array}{l}\text { Drunken, red, } \\
\text { hot, lower, } \\
\text { wilder, } \\
\text { irresponsible, } \\
\text { splendid }\end{array}$ & $\begin{array}{l}\text { Discoursing, } \\
\text { pleading, } \\
\text { screamed, } \\
\text { forgiven, lower, } \\
\text { splendid }\end{array}$ & $\begin{array}{l}\text { Self-recriminatives } \\
\text { Self-aggressives, } \\
\text { self-derogatives }\end{array}$ \\
\hline Excerpt 4 & She, me & & & $\begin{array}{l}\text { Whisper, } \\
\text { Disappear }\end{array}$ & Self-deviatives \\
\hline
\end{tabular}

\section{Conclusion}

The findings show that the process of subjugation of minorities is not simple instead it takes the subjects through the progressive phases, moving from psychological disturbances and loss of identity to resistance, and finally subversion in their archetypal roles. The use of hateful utterances prevails over the world because they carry illocutions of domination over minorities by powerful communities. Hate speech acts have an injurious effect on the psyche of the weak which prompts them to obey the commands of the speakers, the powerful agencies mostly. The humiliating manner, in which the powerful address the weak, creates in the latter a desire to get respect and acceptance from the people who surround them, especially from the people in authoritative positions. This is perhaps the reason why the subject wants to absorb the other into itself. In The Bluest Eye, the white have been 
able to victimize the black psychologically. Their actions and behavior are controlled by them. Their "self" does not have any validation from the hostile environment and is tested against the standards set by the 'others'. Additionally, in hate speech acts, speakers employ sovereign power on the addressees, whom they want to act upon in response to their utterances. Under different slogans such as civilization, religion, race and colour, they try to maintain their own authority over them. They use the authority to crush all those attempts which are likely to threaten their interests. There is always a set of some well determined socio-political agenda based on past, present and future perspectives in the use of sovereign/hate speech acts.

Controverting fixed structures, Butler regards human behavior as constructed under a tangible relationship between human psyche and power of discourse. In the light of the analysis, it can be rightly concluded that people are shaped in language, under language and for language. Nobody is good or bad rather fixity is allocated to their identities with the help of speech. People get energy to live with honour and respect when they are acknowledged by others in a respectful manner and they are mortified when they are abused by others. All the systems, social, political, and moral, can be challenged because they are constructed as well as are controlled under the effects of speech. Speech is used with illocution of making people subjects and the perlocutionary effects of this speech are also reflected in the traumatized and victimized behavior of the subjects. The emerging speech acts in relation to hate speech include other-eliminatives, self-derogatives, other-derogatives, aggressive, self-recriminatives, self-deviatives, and submissives speech acts etc., which pave way for further development of the speech acts theory.

\section{Acknowledgements}

The researchers are greatly obliged to the Department of English Language and Literature, University of Management and Technology, Lahore for providing the encouraging academic atmosphere, required books and electronic devices helpful for this research. The researchers are also thankful to their colleagues for their moral support and valuable feedback required for the improvement of this study.

\section{References}

Adler, E. S., \& Clark, R. (2014). An invitation to social research: How it's done. Nelson Education.

Anderson, E. (2000). The Emerging Philadelphia African American Class Structure. The Annals of the American Academy of Political and Social Science, 568(1), 54-77. https://doi.org/10.1177/000271620056800106

Bouson, J. B. (2000). Quiet as it's kept: shame, trauma, and race in the novels of Toni Morrison. SUNY Press.

Burrows, V. (2004). Whiteness and Trauma: The Mother-Daughter Knot in the Fiction of Jean Rhys. Jamaica Kincaid and Toni Morrison: Palgrave Macmillan New York.

Butler, J. (1996). Bodies that matter.

Butler, J. (1997). Excitable speech: A politics of the performative. Routledge.

Butler, J. (2012). Subjects of desire: Hegelian reflections in twentieth-century France. Columbia University Press.

Butler, J., Laclau, E., Zizek, S., \& Žižek, S. (2000). Contingency, hegemony, universality: Contemporary dialogues on the left. Verso.

Claeys, S. (2007). How to Do Things with Butler. an Inquiry on the Origin, Citation and Application of Judith Butler's Theory of Performativity. Master's thesis, Ghent University. Retrieved from http://lib.ugent.be/fulltxt/RUG01/001/414/561/RUG01-001414561_2010_0001_AC.pdf

Davis, C. A. (1998). Self, society and myth in Toni Morrison's fiction. Toni Morrison, 7-25.

Dixon, M. (1990). Like an Eagle in the Air: Toni Morrison (Bloom, H. ed., pp. 115-142).

Fanon, F. (2008). Black skin, white masks. Grove press.

Fogal, D., Harris, D. W., \& Moss, M. (2018). New Work on Speech Acts. Oxford University Press. https://doi.org/10.1093/oso/9780198738831.001.0001

Hamlin, H., \& Jones, N. W. (2010). The King James Bible after four hundred years: literary, linguistic, and cultural influence. Cambridge University Press. https://doi.org/10.1017/CBO9780511779800

Jaspers, J., Verschueren, J., \& Östman, J.-O. (2010). Society and language use (Vol. 7). John Benjamins Publishing. https://doi.org/10.1075/hoph.7

Lister, R. (2009). Reading Toni Morrison. ABC-CLIO. https://doi.org/10.1075/hoph.7 
Lynn, M., \& Jennings, M. E. (2009). Power, politics, and critical race pedagogy: A critical race analysis of Black male teachers' pedagogy. Race Ethnicity and Education, 12(2), 173-196. https://doi.org/10.1080/13613320902995467

McDowell, D. E. (1988). 'The Self and the Other': Reading Toni Morrison's Sula and the Black Female Text. Critical Essays on Toni Morrison, 77-90.

Milton, J. (1905). Paradise Lost by John Milton. George Routledge and sons, limited.

Moran, J. D. (2015). The Story of a Course on Storytelling. Families, Law, and Literature. USFL Rev., 49(1).

Morrison, T. (1971). The Bluest Eye (1970). New Yorker.

Radin, P., Kerényi, K., \& Jung, C. G. (1972). The trickster: A study in American Indian mythology (Vol. 351): Schocken.

Wang, L. (2011). The uncanny object a in Toni Morrison's fiction.

\section{Notes}

Note 1. Originally published in 1987.

Note 2. The Bluest Eye (1970), Sula (1973), Song of Solomon (1977), Tar Baby (1981), Beloved (1987), Jazz (1992), Paradise (1997), Love (2003), A Mercy (2008), Home (2012), God Help the Child (2015).

Note 3. Lexical semantics finds out how the meaning of different words, their affixes, compound words and phrases, etc. correlates with sentence meaning.

Note 4. In terms of otherness, people realize differences between their own self and the other mostly on grounds of different aspects of social existence such as political, religious, social, cultural, ethnic and gender, etc.

Note 5. Paradise Lost by John Milton is an epic poem in blank verse. Originally published in 1667, it consisted of ten books.

Note 6. Black Skin, White Masks by Frantz Fanon, originally published in 1952.

\section{Copyrights}

Copyright for this article is retained by the author, with first publication rights granted to the journal.

This is an open-access article distributed under the terms and conditions of the Creative Commons Attribution license (http://creativecommons.org/licenses/by/4.0/). 